\title{
Modelling the coupling of flood discharge with glacier flow during jökulhlaups
}

\author{
Jonathan KINGSLAKE, Felix NG \\ Department of Geography, University of Sheffield, UK \\ E-mail: j.kingslake@sheffield.ac.uk
}

\begin{abstract}
We explore a mathematical model that couples together a thermomechanically evolving subglacial channel, distributed cavity drainage, and basal sliding along a subglacial flood path fed by a jökulhlaup lake. It allows water transfer between channel and cavities and a migrating subglacial water divide or 'seal' to form between floods. Notably, it accounts for full coupling between the lake and subglacial drainage in terms of both discharge and pressure, unlike models that neglect the pressure coupling by imposing a known history of lake discharge at the channel inlet. This means that flood hydrographic evolution and its impact on glacier motion are consistently determined by our model. Numerical simulations for a model alpine lake yield stable limit cycles simulating repeating jökulhlaups, with the channel drawing water from the cavities at a varying rate that modulates basal sliding during each flood. A wave of fast sliding propagates down-glacier at flood initiation, followed by deceleration as the growing channel sucks water from the cavities. These behaviours cannot be correctly simulated without the full coupling. We show that the flood's peak discharge, its initiation threshold and the magnitude of the 'fast sliding' wave decrease with the background water supply to the cavities.
\end{abstract}

\section{INTRODUCTION}

In Nye's (1976) jökulhlaup theory, water from a flood lake drains in a subglacial channel whose size evolves to govern the drainage hydrograph. His theory ignores glacier flow due to basal sliding, which may respond to changing subglacial water pressures during floods. Such coupling between floods and ice dynamics is observed in alpine jökulhlaup systems as 'ice-motion' events, such as speed-up (Anderson and others, 2005; Mayer and others, 2008; Riesen and others, 2010; Sugiyama and others, 2010; Bartholomaus and others, 2011) and uplift (e.g. Anderson and others, 2005; Sugiyama and others, 2008; Magnússon and others, 2011) during flood growth followed by deceleration or reversal in ice flow during flood recession (Anderson and others, 2005; Sugiyama and others, 2008; Magnússon and others, 2011). This coupling also occurs in ice sheets. Studies in Greenland show that surface meltwater routed via supraglacial lakes and moulins to the bed can cause short-term changes in surface velocity (Zwally and others, 2002; Das and others, 2008) and seasonal ice speed-up (Bartholomew and others, 2011). These observations raise the question of whether and how much climatewarming induced changes will increase the long-term ice flux (e.g. Schoof, 2010; Sundal and others, 2011). Both alpine marginal lakes and supraglacial lakes are reservoirs whose water balance depends on climate, and drainage-ice-flow coupling in both types of system involves rapid, highmagnitude variations in subglacial discharge; Nye's theory offers a foundation for modelling the physics of this coupling.

Here, considering alpine jökulhlaups only, we present a consistent model of this coupling by extending several strands of previous work. A key feature of Nye's (1976) theory is the growth of channel discharge through positive feedback with melt enlargement of the channel during the rising flood stage. As the lake drains and its level drops, reduced subglacial water pressure promotes channel closure and flood termination. Numerical solution of this model (e.g. Spring and Hutter, 1981; Clarke, 1982, 2003; Ng, 1998; Fowler, 1999, 2009; Ng and Björnsson, 2003; Kessler and
Anderson, 2004; Ng and others, 2007) shows that simulation of jökulhlaup discharge requires full coupling between subglacial drainage and the lake - defined by the two conditions: (1) water flux at the channel inlet equals the lake outflow, and (2) the lake-water depth controls the water pressure at the channel inlet (correctable, in the case of a subglacial lake covered by an ice shelf, for over-pressurization due to vertical shear stresses in the shelf; Evatt and Fowler, 2007). Full coupling is also necessary in any extended model incorporating ice flow and aimed at predicting flood hydrographs.

Recent numerical studies have highlighted the rich hydrological and glacier-dynamical behaviour that can arise when Nye's evolving channel coexists with a distributed drainage system. Flowers and others (2004) showed that lake water injected into a subglacial water sheet, that in turn feeds and rapidly enlarges a channel, can explain the fast-rising discharge seen at the start of the 1996 Grímsvötn (Iceland) flood hydrograph (Björnsson, 2002), not reproducible by Nye's model (Jóhannesson, 2002). Pimentel and Flowers (2011) added other processes to this description - high-order glacier dynamics, basal sliding, ice hydraulic fracture and ice uplift - to explore several glacio-hydraulic scenarios. Since these studies did not focus on flood dynamics, they prescribed a known discharge at the top end of the channel, neglecting condition (2) above. In our model, we use full coupling to let the channel discharge evolve freely, so that the response it causes in distributed drainage and ice flow can feed back and influence lake drainage. The model is used to examine jökulhlaup characteristics and glacier motion during floods. We study specifically whether the incorporation of distributed drainage and ice motion into Nye's theory alters the floods' hydrographs, their initiation threshold and recurrence. Impact of ice motion on supraglacial lake drainage is also conceivable in the ice-sheet scenario, where a supraglacial lake or a moulin acts as a reservoir with more complex geometry than an ice-marginal lake.

A further research strand provides us with a model of distributed drainage and sliding. Hewitt and Fowler (2008) 


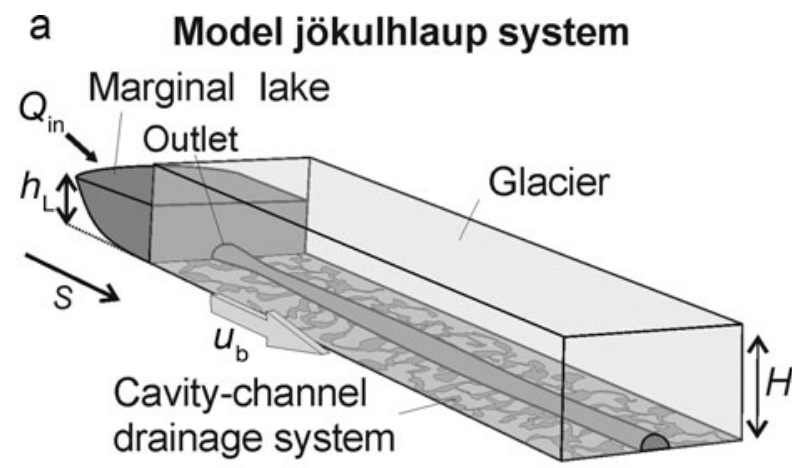

b Plan view of drainage system

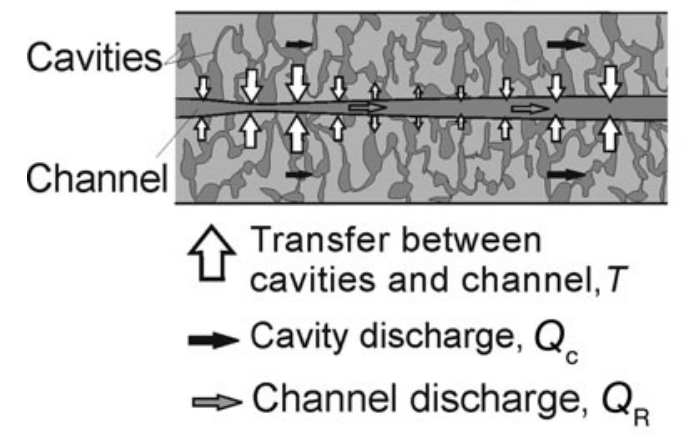

Fig. 1. Diagram of our model jökulhlaup system.

proposed a theory to explain seasonal waves on glaciers. By linking channelized subglacial drainage to cavity drainage with sliding, they showed that imposing periodic meltwater input to this system can cause oscillations in ice flow resembling observations. We adopt some of their cavity system equations below, but couple them to a fully dynamic channel, itself pressure-coupled to a lake. Hewitt and Fowler's way of forcing the system also inspires us to view the background water supply to the cavities $\left(M_{C}\right)$ as an environmental factor behind jökulhlaups.

Our model and its numerical solution are described in Section 2. To gain general insights into alpine and ice-cap jökulhlaup systems, we assume simplified lake and glacier geometry representative of these systems, rather than tailor parameters for a given lake. Section 3 reports our numerical experiments. We show that water transfer from the cavities to the channel can suppress the growth of recurring floods, and we study the spatio-temporal pattern of glacier flow during jökulhlaups. We find that basal sliding is strongly sensitive, but the flood hydrograph weakly sensitive, to $M_{\mathrm{C}}$. We discuss these findings alongside field observations at several jökulhlaup lakes in Section 4.

\section{MATHEMATICAL MODEL}

Figure 1 shows our system. A lake feeds a subglacial channel of length $s_{0}$, which exchanges water with a distributed system of linked cavities outside it; the cavities influence and are influenced by sliding. We denote distance downglacier from the lake by $s$, time by $t$, and use subscripts $\mathrm{R}$ (for Röthlisberger) and C to label channel and cavity variables, respectively. While we aim to couple flood and ice-flow dynamics, three specific 'couplings' occur in the model: between the lake and subglacial drainage, between the channel and cavities, and between cavities and sliding.

\subsection{Channelized drainage}

Nye (1976) envisaged the channel cross-sectional area $S_{\mathrm{R}}$ to evolve under the competition between melt enlargement and creep closure. We use Fowler's (1999) version of his model, which allows the discharge $Q_{R}$ to go negative (e.g. when the channel drains into the lake between floods), and where the equations for channel evolution, mass conservation and momentum conservation, are, respectively:

$$
\begin{gathered}
\frac{\partial S_{\mathrm{R}}}{\partial t}=\frac{m}{\rho_{\mathrm{i}}}-K_{0} S_{\mathrm{R}} N_{\mathrm{R},}^{n} \\
\frac{\partial Q_{\mathrm{R}}}{\partial s}=m\left(\frac{1}{\rho_{\mathrm{w}}}-\frac{1}{\rho_{\mathrm{i}}}\right)+K_{0} S_{\mathrm{R}} N_{\mathrm{R}}^{n}+T\left(N_{\mathrm{R}}, N_{\mathrm{C}}\right), \\
\frac{\partial N_{\mathrm{R}}}{\partial s}=f \rho_{\mathrm{w}} g \frac{Q_{\mathrm{R}}\left|Q_{\mathrm{R}}\right|}{S_{\mathrm{R}}^{\frac{8}{3}}}-\psi .
\end{gathered}
$$

In Eqn (1), the two terms on the right represent melting and closure. The mass melted per unit channel length per unit time, $m$, is given by $m=\left(\psi+\partial N_{R} / \partial s\right)\left|Q_{R}\right| / L$; this expression assumes that potential energy is instantaneously dissipated through friction to melt the channel walls. $N_{R}$ is channel effective pressure $\left(=P_{\mathrm{i}}-P_{\mathrm{R}}\right.$, with $P_{\mathrm{i}}$ being ice overburden pressure, $P_{\mathrm{R}}$ being channel water pressure), $\rho_{\mathrm{w}}$ and $\rho_{\mathrm{i}}$ are water and ice densities, $g$ is gravity, $L$ is latent heat of fusion of water and $f$ is hydraulic roughness $\left(f=n^{\prime 2}\left(R^{2} / S_{R}\right)^{2 / 3} \approx 0.07 \mathrm{~m}^{-2 / 3} \mathrm{~s}^{2}\right.$ for a semicircular channel with wetted perimeter $I$ and Manning's roughness coefficient $n^{\prime}=0.1 \mathrm{~m}^{-1 / 3} \mathrm{~s}$ ). The constants $n=3$ and $K_{0}=10^{-24} \mathrm{~Pa}^{-3} \mathrm{~s}^{-1}$ pertain to temperate ice rheology (Fowler, 1999); $K_{0}$ accounts for the assumed semicircular cross section of the channel.

The term $T$ in Eqn (2) represents the rate of water transfer into the channel from the cavities (volume flux per unit distance). Following Hewitt and Fowler (2008) we model it as proportional to the pressure difference between these drainage components:

$$
T=R_{\mathrm{k}} k\left(N_{\mathrm{R}}-N_{\mathrm{C}}\right),
$$

where $N_{C}$ is the cavity effective pressure and $k$ is a connectivity constant (we adopt Hewitt and Fowler's value $\left.10^{-9} \mathrm{~m}^{2} \mathrm{~s}^{-1} \mathrm{~Pa}^{-1}\right) . R_{\mathrm{k}}$ is a dimensionless factor used in our experiments (Section 3.1) for varying the transfer rate $R_{\mathrm{k}} k$ that saves us from writing out its units each time.

Equation (3) derives from Manning's friction formula and $\psi$ is the basic hydraulic gradient, given by

$$
\psi=\rho_{\mathrm{w}} g \sin \phi_{\mathrm{b}}-\frac{\partial P_{\mathrm{i}}}{\partial s}
$$

where $\phi_{\mathrm{b}}$ is the glacier bed slope. We assume a slab glacier with uniform thickness $H$ (Fig. 1), so $\psi$ is constant.

Equations (1-3) neglect the lake's internal energy that could enhance the channel melt rate $m$ (Clarke, 1982), so this model assumes lake and subglacial water temperatures equal to the pressure-melting point. Also, as $N_{R}$ and $N_{C}$ stay positive in our simulations, we do not model channel enlargement caused by ice uplift when $N_{R}$ or $N_{C} \leq 0$ (Jóhannesson, 2002; Hewitt and others, 2012).

\subsection{Lake evolution}

The lake depth $h_{\mathrm{L}}$ (Fig. 1) evolves with water input $\left(Q_{\text {in }}\right)$ and outflow $\left(Q_{\mathrm{R}}\right.$ at the channel inlet) following the continuity equation

$$
\frac{\mathrm{d} h_{\mathrm{L}}}{\mathrm{d} t}=\frac{1}{A_{\mathrm{L}}}\left[Q_{\text {in }}-Q_{\mathrm{R}}(0, t)\right]
$$


where $A_{\mathrm{L}}$ is uniform lake area. Equation (6) expresses condition (1) of our full coupling (Section 1). According to condition (2) of our full coupling, the hydrostatic lake pressure fixes the channel-inlet effective pressure to be

$$
N_{\mathrm{R}}(0, t)=\rho_{\mathrm{i}} g H-\rho_{\mathrm{w}} g h_{\mathrm{L}}(t)
$$

at all times, and this provides a boundary condition for $N_{R}$ in Eqn (3).

\subsection{Linked-cavity drainage and basal sliding}

We follow Hewitt and Fowler (2008) in using a pseudosteady description for the geometry of the cavities, with a conservation equation for the water flux through them and a sliding law. For sliding at velocity $u_{\mathrm{b}}$ over bed obstacles of height $R$, Walder (1986) showed that the typical cavity crosssectional area is

$$
S_{\mathrm{c}}=\frac{\pi}{4}\left[R u_{\mathrm{b}}+(1-\gamma) \frac{Q_{\mathrm{c}}}{L k_{1} \rho_{\mathrm{i}}}\left(\frac{\partial N_{\mathrm{c}}}{\partial s}+\psi\right)\right] \frac{1}{K_{0}}\left(\frac{n}{N_{\mathrm{c}}}\right)^{n},
$$

where $\gamma \approx 0.32$ and $k_{1} \approx 1.1$ are constants, and that the water discharge through the cavity system, $Q_{C}$, depends on hydraulic gradient (just as for the channel) so that $Q_{C}$ and $S_{\mathrm{C}}$ are related via

$$
S_{\mathrm{c}}=\left(\frac{\pi R}{4 k_{1}}\right)^{-\frac{2}{3}}\left(\rho_{\mathrm{w}} g\right)^{\frac{1}{2}} \sqrt{\frac{f}{6.6}} Q_{\mathrm{c}}\left(\frac{\partial N_{\mathrm{c}}}{\partial s}+\psi\right)^{-\frac{1}{2}} .
$$

We adopt a power law to describe sliding,

$$
u_{\mathrm{b}}=c_{s} \frac{\tau_{\mathrm{b}}^{p}}{N_{\mathrm{c}}^{q}}
$$

(e.g. Bindschadler, 1983), where $p=4, q=1, c_{s}$ is a constant dependent on bed roughness $\left(\approx 2 \times 10^{-20} \mathrm{~m} \mathrm{~s}^{-1} \mathrm{~Pa}^{-3}\right.$; Hewitt and Fowler, 2008), and $\tau_{\mathrm{b}}$ is the basal shear stress assumed to balance local driving stress $\rho_{\mathrm{i}} g H \sin \phi_{\mathrm{s}}$ where $\phi_{\mathrm{s}}$ is glacier surface slope (Cuffey and Paterson, 2010). Following Walder (1986) and Kamb (1987), we assume that the sliding control on cavity size (the first of the two terms enclosed by the square brackets in Eqn (8)) dominates frictional heating (the second term). On neglecting the latter term, eliminations between Eqns (8) and (10) lead to

$$
N_{\mathrm{c}}=\left[\frac{\pi R C_{s} n^{n}}{4 K_{0}}\left(\frac{\tau_{\mathrm{b}}^{p}}{S_{\mathrm{C}}}\right)\right]^{\frac{1}{n+q}}
$$

and

$$
u_{\mathrm{b}}=\left[\left(c_{\mathrm{s}} \tau_{\mathrm{b}}^{p}\right)^{n}\left(\frac{4 K_{0}}{\pi R n^{n}} S_{\mathrm{c}}\right)^{q}\right]^{\frac{1}{n+q}},
$$

which give the cavity effective pressure and sliding velocity in terms of $S_{\mathrm{C}}$. For the bed obstacle height $R$, we use Walder's (1986) value of $0.1 \mathrm{~m}$.

A final equation describes water conservation in the cavities:

$$
\frac{\partial S_{\mathrm{C}}}{\partial t}=M_{\mathrm{C}}-\frac{\partial Q_{\mathrm{C}}}{\partial s}-T
$$

where $M_{C}$ is the background water supply to the cavities from basal- and surface-derived melt. We assume that the channel receives meltwater only via the cavities (through $T$ ) and none directly via moulins or other englacial routes.

Equations (1-6), (9), (11a), (11b) and (12) complete our model. In essence it describes the coupled evolution of channel size, cavity size, and lake level. $S_{R}, Q_{R}, N_{R}, T, S_{C}$, $Q_{\mathrm{C}}, N_{\mathrm{C}}$ and $u_{\mathrm{b}}$ are functions of $t$ and $s$, while $h_{\mathrm{L}}$ is a function of $t$ only. This model differs from Hewitt and Fowler's not just in its inclusion of the lake and a channel that evolves at a rate dictated by melt and ice creep, but also in using the total hydraulic gradients $\psi>+\partial \mathrm{N}_{R} / \partial s$ and $\psi+\partial N_{C} / \partial s$ to drive channel and cavity flow (rather than $\psi$ alone). Four boundary conditions are needed in Eqns (2), (3), (9) and (12) for determining the discharge and pressure in these systems. For the channel we impose the condition in Eqn (7) and $N_{R}=0$ at the terminus $\left(s=s_{0}\right)$. For the cavities, an equation like (7) could be used to couple the cavities and the lake hydraulically. Preliminary investigations indicate that interesting dynamics result from this coupling, but a full exploration of its consequences is beyond our scope here. Instead, for simplicity, we isolate the cavities from the lake, by assuming that $N_{C}$ at the lake $(s=0)$ and at the terminus $\left(s=s_{0}\right)$ are both constant, $\approx 1 \times 10^{5} \mathrm{~Pa}$. Although this value may seem arbitrary, the qualitative features of our results reported below are not sensitive to its size.

Our assumption of pseudo-steady cavity geometry is motivated by the supposition that, unlike in channels, the cavity system's effective pressure-discharge relationship will be negative whether the system is steady or not, and motivated by the lack of unsteady cavity drainage models that are strongly verified by subglacial observations. However, the potential limitations of our model need to be recognized. Since, in reality, cavity size will not react instantaneously to pressure changes, our model overestimates the role of water storage in cavities when water transfer changes rapidly and neglects the lag of peak cavity size behind peak cavity water pressure. In such situations, the model will underestimate actual $N_{C}$ and $u_{b}$ variations. Also, our model precludes investigation of a possible negative feedback between cavity size and pressure suggested by Bartholomaus and others (2011). In a recent theory, Hewitt and others (2012) have tried to overcome these limitations by modelling the cavity system dynamically as a sheet with a cavity evolution equation analogous to Eqn (1).

\subsection{Method of numerical solution}

We solved the equations with the finite-difference method on a discretized space-time domain. The forward Euler method was used to integrate Eqns (1), (6) and (12), with upwinding for the spatial derivative in Eqn (12). When calculating results at the next time-step, we first used variables from the current time-step to update the lake depth $h_{\mathrm{L}}$ and cavity area $S_{\mathrm{C}}$, from which the sliding velocity $u_{\mathrm{b}}$, cavity discharge $Q_{\mathrm{C}}$ and pressure $N_{C}$ could be found by Eqns (11) and (9). Turning to the channel, we then used Eqn (1) to update $S_{R}$, and used $S_{R}$ in Eqns (2) and (3) (with their boundary conditions and $N_{C}$ at the new time) to find the discharge and pressure distributions $Q_{R}$ and $N_{R}$ at the new time-step. In this boundary-value problem, where (and whether) $Q_{R}$ switches sign along the channel is not known a priori. To overcome this we solved Eqns (2) and (3) by two nested iteration loops. In the inner loop, a guess of the lake outflow $Q_{\mathrm{R}}(s=0)$ at the new time was used as the boundary condition for integrating Eqn (2) into $s>0$. We used dynamic relaxation for Eqn (2) and introduced a fictitious $\varepsilon \partial Q_{\mathrm{R}} / \partial t$ to its left-hand side, and iterated $Q_{\mathrm{R}}$ to steady state on the fast $(\varepsilon)$ timescale. This inner loop thus yields the $Q_{R}$ and $N_{R}$ distributions simultaneously, including the channel effective pressure at its inlet, $N_{R}(s=0)$. Generally, $Q_{R}(s=0)$ and $N_{R}(s=0)$ at the new timestep from this loop mismatch the lake condition in Eqn (7). In the outer loop, we use the Newton-Raphson method to correct the guess of $Q_{R}(s=0)$ iteratively (letting the inner loop converge each time) to obtain the match. 


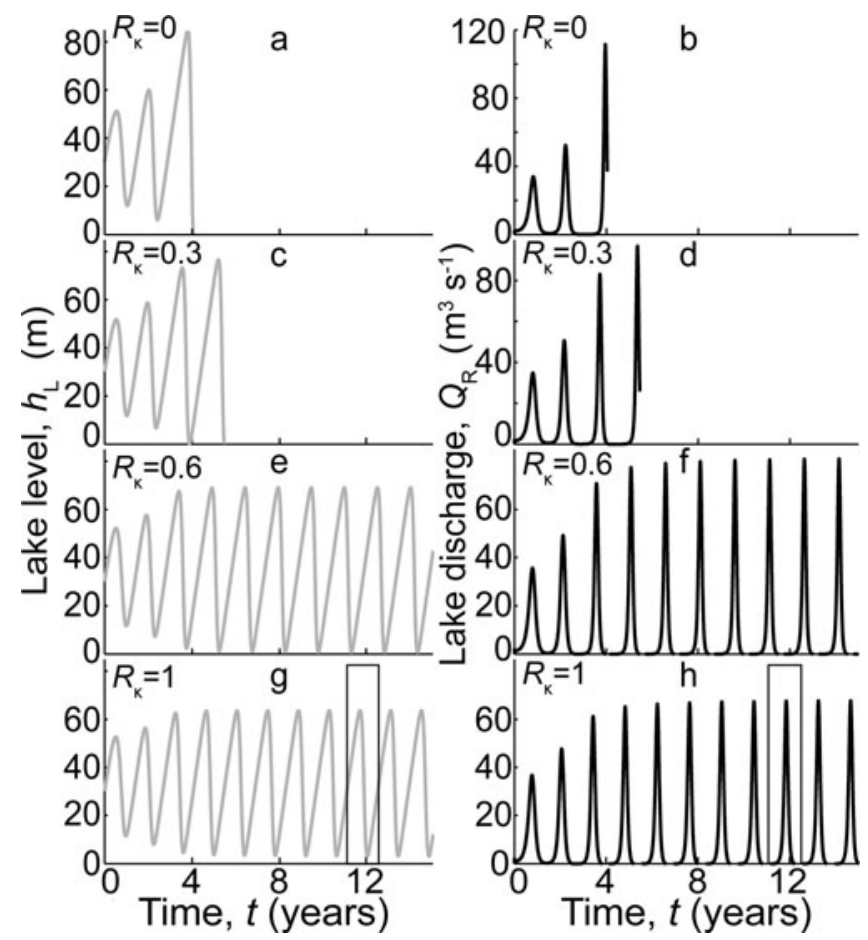

Fig. 2. Modelled lake level, $h_{\mathrm{L}}(t)$ (left), and channel discharge at the lake, $Q_{\mathrm{R}}(0, t)$ (right), for $R_{\mathrm{k}}=0,0.3,0.6$ and 1 . Cavity water supply, $M_{\mathrm{C}}=1 \times 10^{-3} \mathrm{~m}^{2} \mathrm{~s}^{-1}$.

\section{RESULTS OF NUMERICAL SIMULATIONS}

We report here numerical experiments made with the model to study (1) the cyclicity of recurring floods, (2) variations in ice flow in each jökulhlaup cycle, and (3) sensitivity of these variations to the cavity water supply, $M_{C}$. Throughout, a lake with area $A_{\mathrm{L}}=5 \mathrm{~km}^{2}$, and a glacier described by parameters $s_{0}=10 \mathrm{~km}, H=100 \mathrm{~m}$ and $\sin \phi_{\mathrm{s}}=\sin \phi_{\mathrm{b}}=0.01$, are assumed. These values pertain to Merzbacher Lake and South Inylchek Glacier, Kyrgyzstan ( $\mathrm{Ng}$ and Liu, 2009), and lead to $\psi \approx 100 \mathrm{~Pa} \mathrm{~m}^{-1}$ and $\tau_{\mathrm{b}} \approx 9 \mathrm{kPa}$.

\subsection{Flood cycles}

Nye's model formulated with only time dependence and no spatial dependence can simulate recurring floods, but their size grows indefinitely with time through a feedback between decreasingly small channel size and increasing highstand and peak discharge $(\mathrm{Ng}, 1998 ; \mathrm{Ng}$ and Björnsson, 2003). In reality many jökulhlaups terminate through complete emptying of the lake, which would interrupt such unbounded growth, but $\mathrm{Ng}$ and Björnsson (2003) also found this behaviour when simulating floods from Grímsvötn, Iceland, which does not empty (Björnsson, 2002). Consequently, unbounded flood growth is seen as an intrinsic weakness of some jökulhlaup models. Fowler (1999) showed that model flood cycles remain bounded if spatial dependence is included, the channel receives a uniform meltwater supply and the basic hydraulic gradient near the lake is negative (e.g. due to retrograde ice-dam surface slope towards the lake - a 'topographic seal'). Whether uniform channel supply and a topographic seal are necessary conditions for bounded flood cycles has remained unexplored. As our model treats how the channel captures subglacial water in more detail than Fowler's model and uses a positive basic hydraulic gradient everywhere, we address this by asking whether we can simulate stable flood cycles.
Figure 2 shows the simulated time series from a set of model runs, each spanning 15 model years and conducted with an initial lake depth of $30 \mathrm{~m}\left(h_{\mathrm{L}}\right.$ at $\left.t=0\right)$, a constant lake-water input $Q_{\text {in }}=10 \mathrm{~m}^{3} \mathrm{~s}^{-1}$, a constant background water supply to cavities $M_{\mathrm{C}}=1 \times 10^{-3} \mathrm{~m}^{2} \mathrm{~s}^{-1}$, and several values of the parameter $R_{\mathrm{k}}$ between 0 and $1 . R_{\mathrm{k}}=0$ and $R_{\mathrm{k}}=1$ refer to total hydraulic isolation and the hydraulic coupling used by Hewitt and Fowler (2008), respectively. The coupled lake-channel-cavity system oscillates in time, yielding asymmetric filling and draining cycles of lake depth (Fig. 2a, c, e and g) and corresponding floods in the channel discharge (Fig. 2b, $d, f$ and h). In all runs, initially, the volume and peak size of successive floods increase with time in a transient response to initial conditions. When $R_{\mathrm{k}} \leq 0.3$, the lake's post-flood 'lowstand' level decreases until the lake empties completely, interrupting the simulation (Fig. $2 \mathrm{a}-\mathrm{d}$ ). In contrast, when $R_{\mathrm{k}} \geq 0.6$, the cycles become periodic and stable without emptying the lake (Fig. 2e-h). Runs using $0.3<R_{\mathrm{k}}<0.6$ (not shown) show that increasing $R_{\mathrm{k}}$ delays the emptying of the lake as peak discharge is suppressed by increased cavity-to-channel water transfer.

These results go beyond Fowler's to show that stable limit cycles occur when high $T$ values allow the channel to capture water efficiently from the cavities and a water divide (or seal) to form between floods. The stabilizing effect of this transfer is evidenced also by the impact of $R_{\mathrm{k}}$ on the cycles: the higher is $R_{\mathrm{k}}$, the shorter is their period and the smaller the flood volumes. Furthermore, we show that the channel can drain water into the lake at low lake levels and stable flood cycles can occur even if the basic hydraulic gradient is positive everywhere: a topographic seal is not a necessary condition for water divide formation.

\subsection{Spatio-temporal evolution of sliding and drainage}

The periodicity of stable cycles provides us with a common basis for studying individual floods and how their characteristics depend on model parameters, without the obstacles associated with initial conditions. Here we analyse the spatio-temporal behaviour of subglacial drainage and ice flow in the $(\approx 1.5$ year long) flood cycle highlighted by the boxes in Figure $2 \mathrm{~g}$ and $\mathrm{h}$.

Figure 3 shows the simulated lake depth $h_{\mathrm{L}}(t)$ and lake outflow $Q_{R}(s=0, t)$ (Fig. 3a), basal sliding velocity $u_{\mathrm{b}}(s, t)$ (Fig. 3b) and rate of cavity-to-channel water transfer $T(s, t)$ (Fig. 3c) through the cycle. Figure $3 \mathrm{c}$ is a map of Tover time and distance; a similar map is also used to plot $u_{\mathrm{b}}(s, t)$ in Figure 4c, studied in Section 3.3. The hydrographic sequence here has been discussed by Fowler (1999). In Figure $3 \mathrm{~b}$, the time before point $\mathrm{A}$ (and after point $\mathrm{E}$ of the last cycle) is the lake-refilling phase between successive floods. At point A, high lake level moves the subglacial 'seal' (water divide in the channel) back to the lake, initiating the flood and allowing Nye's positive feedback to enlarge the channel. B marks the time of the lake-level highstand when the flood's growing discharge instantaneously matches the lake-water input. C and D mark the flood peak and the postflood lake lowstand, respectively.

Regarding ice motion, Figure $3 \mathrm{~b}$ shows similar responses in $u_{\mathrm{b}}$ at different positions on the glacier. $u_{\mathrm{b}}$ rises gradually as the lake fills, but accelerates rapidly after flood initiation (A) to peak soon after the time of the lake highstand (B). $u_{\mathrm{b}}$ drops during the main flood ( $B$ to $D$ ) to a much lower velocity than during lake refilling, then increases again after 


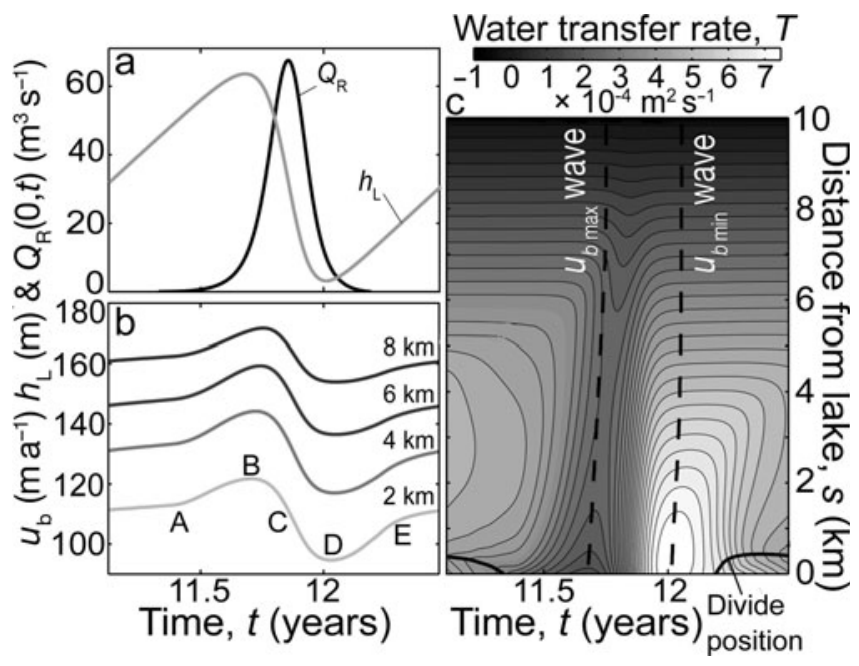

Fig. 3. Evolution of (a) lake level, $h_{\mathrm{L}}(t)$, and channel discharge at the lake, $Q_{\mathrm{R}}(0, t)$; (b) sliding velocity, $u_{\mathrm{b}}(s, t)$; and (c) cavity-channel water transfer rate, $T(s, t)$ in the limit cycle indicated by the boxes in Figure $2 \mathrm{~g}$ and $\mathrm{h} . M_{\mathrm{C}}=1 \times 10^{-3} \mathrm{~m}^{2} \mathrm{~s}^{-1}, R_{\mathrm{k}}=1$.

flood termination ( $\mathrm{D}$ to $\mathrm{E}$ ). The durations of elevated and depressed $u_{\mathrm{b}}$ are comparable. Spatially, $u_{\mathrm{b}}$ rises monotonically with distance down-glacier, but its time variations at different positions are not precisely synchronous. Figure $3 \mathrm{~b}$ shows that the peak and trough in $u_{\mathrm{b}}$ propagate down-glacier at $\approx 250 \mathrm{~m} \mathrm{~d}^{-1}$ and $\approx 450 \mathrm{~m} \mathrm{~d}^{-1}$, respectively (see the dashed lines in Fig. 3c).

This sliding response can be explained by considering our model's physics and is the direct result of the full coupling between the lake and the drainage system. Equation (11b) shows that $u_{\mathrm{b}}$ varies directly with cavity size, $S_{\mathrm{C}}$. In turn, $S_{\mathrm{C}}$ depends on how much water the cavities gain from the background supply $M_{C}$ and lose to the channel via water transfer, whose rate $T$ increases with channel effective pressure, $N_{R}$ (Eqns (12) and (4)). The sliding response thus stems ultimately from changes in lake level, which, through its effect on the channel pressure, governs how fast the channel draws water from the cavities. The timing associations in Figure 3 between $h_{\mathrm{L}}, T$ and $u_{\mathrm{b}}$ confirm this explanation. When the lake fills between floods ( $E$ to $A$ ), reducing $N_{R}$ at the channel inlet, its hydrostatic pressure is not transmitted past the seal (located in Fig. 3c by the black line) to modulate $T$ and $u_{\mathrm{b}}$ directly far down-glacier (further simulations show that this effect would be diminished if the cavities and lake were coupled hydraulically); there is a slight increase in $u_{\mathrm{b}}$ only because the lake level weakly affects the distributions of $N_{R}$ and $T$ in the channel through its control on the migrating seal position. However, after the flood starts at $t \approx 11.4$ years, the seal's absence means that the pressure transmission is unimpeded and able to reduce $N_{R}$ and $T$ markedly down most of the channel (see descent into the dark trough in Fig. 3c); this causes the cavities to expand and accelerates sliding ( $A$ to $B ; 11.4<t<11.7$ years). Later, as flood discharge grows, peaks, and recedes under Nye's mechanisms (B to D, $11.7<t<12$ years), the lake level drops rapidly, raising $N_{R}$ along the channel so that enhanced water transfer out of the cavities shrinks their size and decelerates sliding. After the seal re-forms at flood termination $(\mathrm{E}, t \approx 12.2$ years) we enter a new cycle. During the flood when the lake strongly modulates the cavity-tochannel water transfer, the nonlinear wave properties of Eqns (1-3) determine the propagation of changes in $T$ and $u_{\mathrm{b}}$ down the channel.

\subsection{Sensitivity to the cavity background supply, $M_{C}$}

Finally, we study how the ice-flow and flood evolution depends on the supply $M_{\mathrm{C}}$, which is the other control on cavity drainage beside $T$. For temperate glaciers, $M_{C}$ likely encompasses water reaching the bed from the surface, so it can be viewed as a proxy for weather conditions.

Figure $4 \mathrm{a}-\mathrm{d}$ plot the maps of $u_{\mathrm{b}}(s, t)$ and time series of lake outflow from four model runs that assumed different values of $M_{\mathrm{C}}$ between $2 \times 10^{-4}$ and $2 \times 10^{-3} \mathrm{~m}^{2} \mathrm{~s}^{-1}$. Each plot's duration is one flood cycle. The third run (Fig. 4c), identical to that discussed in Section 3.2, serves as the control. An enduring pattern in these runs is that the ice flow speeds up after flood initiation and begins to decelerate before the flood peaks. In the run with the lowest $M_{C}$ (Fig. 4a), the speed-up is very sudden and a strong compression wave $\left(\partial u_{\mathrm{b}} / \partial s<0\right)$ propagates down-glacier some 70 days prior to the flood peak (around $12.5<t<12.7$ years).
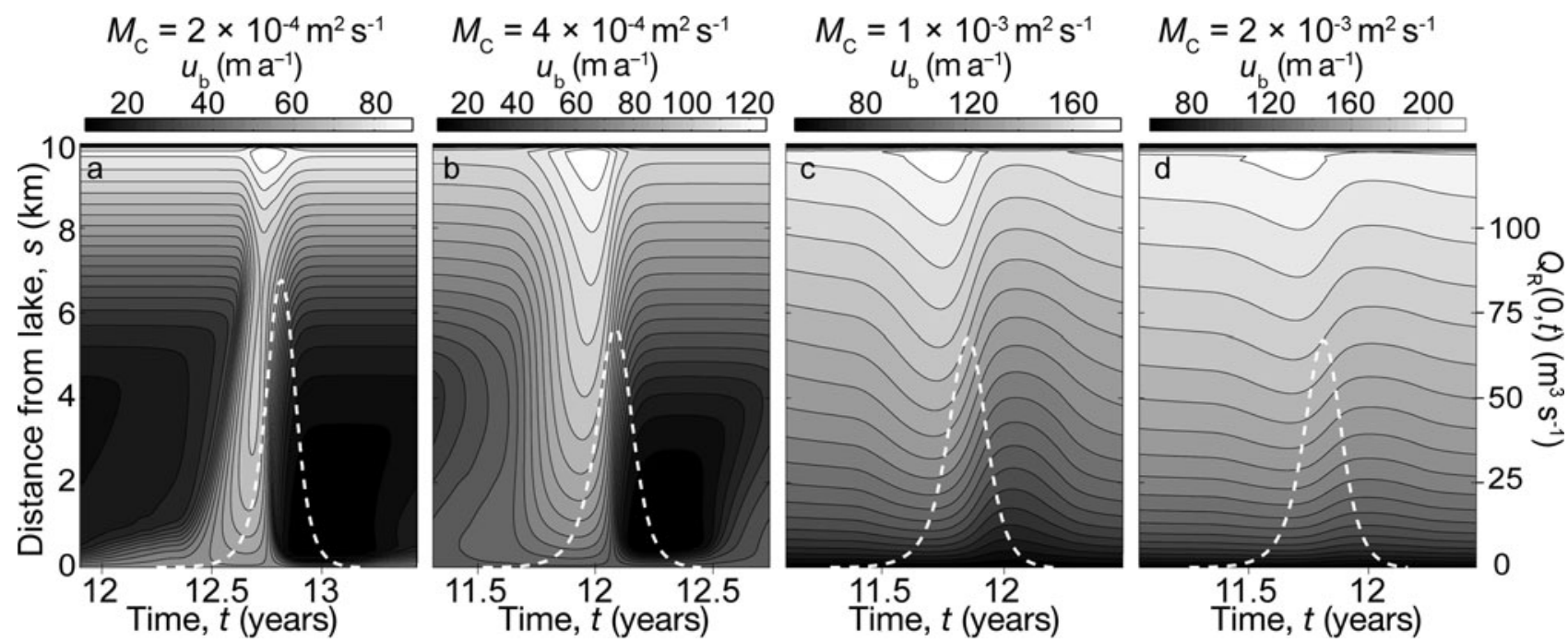

Fig. 4. Sliding velocity $u_{\mathrm{b}}(s, t)$ (filled contour maps) and channel discharge at the lake $Q_{\mathrm{R}}(0, \mathrm{t})$ (white dashed lines and right-hand vertical axis) in one limit cycle for (a) $M_{C}=2 \times 10^{-4} \mathrm{~m}^{2} \mathrm{~s}^{-1}$, (b) $M_{\mathrm{C}}=4 \times 10^{-4} \mathrm{~m}^{2} \mathrm{~s}^{-1}$, (c) $M_{\mathrm{C}}=1 \times 10^{-3} \mathrm{~m}^{2} \mathrm{~s}^{-1}$ and (d) $M_{\mathrm{C}}=2 \times 10^{-3} \mathrm{~m}^{2} \mathrm{~s}^{-1}$. 


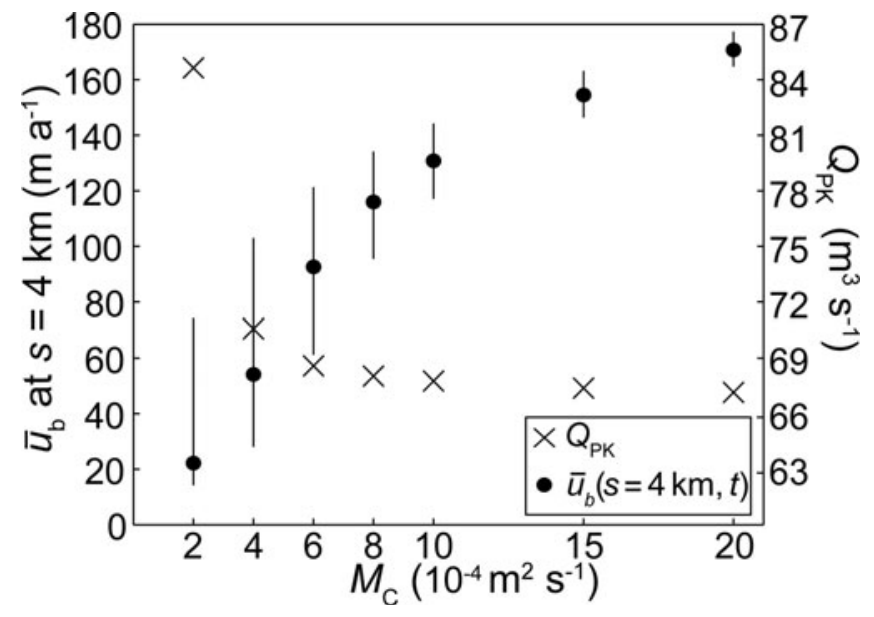

Fig. 5. Mean sliding velocity at $4 \mathrm{~km}$ from the lake, $u_{\mathrm{b}}$ (circles and left axis), and peak lake discharge, $Q_{\mathrm{PK}}$ (crosses and right axis), for $M_{\mathrm{C}}=2 \times 10^{-4} \mathrm{~m}^{2} \mathrm{~s}^{-1}$ to $2 \times 10^{-3} \mathrm{~m}^{2} \mathrm{~s}^{-1}$. The top and bottom ends of the vertical lines indicate maximum and minimum $u_{\mathrm{b}}$ at $4 \mathrm{~km}$ from the lake.

Physically, we expect that decreasing $M_{C}$ reduces cavity size and discharge via mass conservation (Eqn (12)), and hence reduces the sliding velocity $u_{\mathrm{b}}$ (Eqn (11a)). We see this trend in Figure $4 a-d$ (note their different scales) as we move from right to left; however, the percentage variation in $u_{\mathrm{b}}$ in the cycles increases. Figure 5 quantifies both trends by plotting the mean, maximum and minimum values of $u_{\mathrm{b}}$ at $4 \mathrm{~km}$ from the lake in each cycle, including results from extra runs where $M_{C}$ is varied within the same range. As $M_{C}$ is raised, the mean value of $u_{\mathrm{b}}$ increases but its maximum-tomean ratio decreases.

We expect two outcomes of decreased $M_{C}$ on cavitychannel interaction. One is increased dominance of the transfer term in the cavity mass conservation equation (Eqn (12)). This explains the variable maximum-to-mean $u_{\mathrm{b}}$ ratio; when $M_{\mathrm{C}}$ is large, the remaining, time-varying terms in Eqn (12), $\partial Q_{\mathrm{C}} / \partial s$ and $T$, are comparatively small and $S_{\mathrm{C}}$ and $u_{\mathrm{b}}$ vary less than when $M_{\mathrm{C}}$ is small; then, $S_{\mathrm{C}}$ and $u_{\mathrm{b}}$ are modulated strongly because $T$ dominates the mass balance. In addition, when $M_{\mathrm{C}} \leq 4 \times 10^{-4} \mathrm{~m}^{2} \mathrm{~s}^{-1}$, the cavities collapse after the lake reaches its highstand due to high effective pressure in the channel, preventing significant reduction of $u_{\mathrm{b}}$ below its mean value (Fig. 5); then, most of the background water supply to the cavities reaches the channel, and the cavity area is controlled by $M_{\mathrm{C}}=k\left(N_{\mathrm{R}}-N_{\mathrm{C}}\right)$ and Eqn (11a). In the case where $M_{C}=2 \times 10^{-4} \mathrm{~m}^{2} \mathrm{~s}^{-1}$, the cavity system does not recover until after the divide reaches the lake (Fig. $4 \mathrm{a} ; t \approx 12.3$ years). These model results imply that under cold weather conditions when subglacial water is less abundant, glacier flow velocities would be lower during quiescence but respond more strongly in absolute and relative magnitudes to subglacial floods.

The other expected outcome of decreasing $M_{\mathrm{C}}$ is that the cavity effective pressure $N_{C}$ increases (Eqn (11a)), reducing water transfer $T$ to the channel (Eqn (4)). Analysis of channel equations (1-3) shows that the seal then migrates more slowly towards the lake as it refills; this delays flood initiation, so the lake reaches a higher highstand - a higher flood initiation threshold, to cause a higher flood peak discharge, $Q_{\mathrm{PK}}$. Figures 4 and 5 show that the negative dependence of $Q_{\mathrm{PK}}$ on $M_{\mathrm{C}}$ is nonlinear and becomes sensitive only for $M_{C}<6 \times 10^{-4} \mathrm{~m}^{2} \mathrm{~s}^{-1}$.

\section{DISCUSSION AND CONCLUSIONS}

We have presented the first fully coupled and consistent jökulhlaup model capable of explaining the broad pattern of observed sliding velocity changes during jökulhlaups. At Gornergletscher, Switzerland, and the Grímsvötn and Skaftá subglacial cauldrons, Iceland, sliding velocity increases during flood growth and, at Gornergletscher and Skaftá, it decreases during flood recession (Magnússon and others, 2007; Sugiyama and others, 2010). At Gornergletscher, ice surface motion has been observed to reverse following the slowdown (Sugiyama and others, 2007), with maximum sliding velocity occurring before peak flood discharge. Our model reproduces this timing and the marked post-flood sliding deceleration (e.g. in Fig. 3a and b). In contrast, at Hidden Creek Lake, Alaska, maximum sliding velocity peak occurs after peak discharge (Anderson and others, 2005; Bartholomaus and others, 2011).

These observations reveal variability in the hydrodynamic behaviour of jökulhlaup systems that stems from their glaciological and environmental factors, factors which may be difficult to constrain with field data. However, future work can use our model to investigate whether differences in drainage system connectivity, lake and glacier geometry, cavity water supply, lake input, sliding parameterization or a combination of these can account for observed variability. For example, our assumed basal shear stress, $\tau_{\mathrm{b}}$, is relatively low $\left(\tau_{\mathrm{b}} \approx 9 \mathrm{kPa}\right.$; based on the thin ice dam at Merzbacher Lake). Preliminary study shows that increasing $\tau_{\mathrm{b}}$ results in a monotonic increase in $u_{\mathrm{b}}$ and decrease in maximum-tomean $u_{\mathrm{b}}$ ratio. Also, the duration of our simulated floods is unrealistically large, lasting months rather than weeks. This is due to our assumed model parameters; model runs using lake and glacier geometries, and lake and cavity water supplies, derived from observations at Gornergletscher (Sugiyama and others, 2010) and Hidden Creek Lake, Alaska (Bartholomaus and others, 2011), simulate more realistic, shorter-duration floods. These modelling explorations will be reported elsewhere.

Observed flood initiation thresholds provide another example of jökulhlaup variability ( $\mathrm{Ng}$ and Liu, 2009). Modelled flood thresholds vary with the cavity water supply (Fig. 2; Section 3.1) and the lake input. This behaviour reveals a link between weather and flood timing. We are exploiting this link during ongoing work, aimed at quantifying the predictability of jökulhlaup timing, by implementing a suite of lower-order models that account for weatherinduced variations in the flood-initiation threshold.

Like previous work (e.g. Hewitt and Fowler, 2008; Pimentel and Flowers, 2011; Hewitt and others, 2012), we model drainage one-dimensionally. This ignores lateral propagation of variations in $N_{C}$ within the cavity system, the velocity of which may be comparable to their downglacier propagation velocities. Hewitt (2011) recently used a two-dimensional channel-distributed system model to investigate the steady-state spacing of channels beneath ice sheets. It may be possible to extend our present model with his formulation to study the lateral processes in distributed drainage during our subglacial floods.

What are the implications of our model for the coupling between subglacial drainage and ice motion in an ice-sheet setting? Our results introduce the possibility that supraglacial lake drainage in Greenland could, depending on basal conditions, cause both ice speed-up and slowdown. This awaits further exploration, using parameters associated 
with the thicker ice, reduced basic hydraulic gradients, and lower basal shear stress typical of ice sheets while treating Greenland supraglacial lake and moulin drainage as analogues of alpine jökulhlaup systems.

\section{ACKNOWLEDGEMENTS}

J. Kingslake acknowledges the support of a University of Sheffield PhD Studentship. We thank G. Flowers and T. Jóhannesson for editorial comments and C. Schoof and G. Clarke for careful and constructive reviews, all of which greatly improved the manuscript.

\section{REFERENCES}

Anderson RS, Walder JS, Anderson SP, Trabant DC and Fountain AG (2005) The dynamic response of Kennicott Glacier, Alaska, USA, to the Hidden Creek Lake outburst flood. Ann. Glaciol., 40, 237-242 (doi: 10.3189/172756405781813438)

Bartholomaus TC, Anderson RS and Anderson SP (2011) Growth and collapse of the distributed subglacial hydrologic system of Kennicott Glacier, Alaska, USA, and its effects on basal motion. J. Glaciol., 57(206), 985-1002 (doi: 10.3189/ 002214311798843269)

Bartholomew ID and 6 others (2011) Seasonal variations in Greenland Ice Sheet motion: inland extent and behaviour at higher elevations. Earth Planet. Sci. Lett., 307(3-4), 271-278 (doi: 10.1016/j.epsl.2011.04.014)

Bindschadler R (1983) The importance of pressurized subglacial water in separation and sliding at the glacier bed. J. Glaciol., 29(101), 3-19

Björnsson H (2003) Subglacial lakes and jökulhlaups in Iceland. Global Planet. Change, 35(3-4), 255-271 (doi: 10.1016/S09218181(02)00130-3)

Clarke GKC (1982) Glacier outburst floods from 'Hazard Lake', Yukon Territory, and the problem of flood magnitude prediction. J. Glaciol., 28(98), 3-21

Clarke GKC (2003) Hydraulics of subglacial outburst floods: new insights from the Spring-Hutter formulation. J. Glaciol., 49(165), 299-313 (doi: 10.3189/172756503781830728)

Cuffey KM and Paterson WSB (2010) The physics of glaciers, 4th edn. Butterworth-Heinemann, Oxford

Das SB and 6 others (2008) Fracture propagation to the base of the Greenland Ice Sheet during supraglacial lake drainage. Science, 320(5877), 778-781 (doi: 10.1126/science.1153360)

Evatt GW and Fowler AC (2007) Cauldron subsidence and subglacial floods. Ann. Glaciol., 45, 163-168 (doi: 10.3189/ 172756407782282561)

Flowers GE, Björnsson H, Pálsson R and Clarke GKC (2004) A coupled sheet-conduit mechanism for jökulhlaup propagation. Geophys. Res. Lett., 31(5), L05401 (doi: 10.1029/ 2003GL019088)

Fowler AC (1999) Breaking the seal at Grímsvötn, Iceland. J. Glaciol., 45(151), 506-516

Fowler AC (2009) Dynamics of subglacial floods. Proc. R. Soc. London, Ser. A, 465(2106), 1809-1828 (doi: 10.1098/rspa. 2008.0488)

Hewitt IJ (2011) Modelling distributed and channelized subglacial drainage: the spacing of channels. J. Glaciol., 57(202), 302-314 (doi: 10.3189/002214311796405951)

Hewitt IJ and Fowler AC (2008) Seasonal waves on glaciers. Hydrol. Process., 22(19), 3919-3930 (doi: 10.1002/hyp.7029)

Hewitt IJ, Schoof C and Werder MA (2012) Flotation and free surface flow in a model for subglacial drainage. Part 2. Channel flow. J. Fluid Mech., 702, 157-187 (doi: 10.1017/jfm.2012.166)

Jóhannesson T (2002) Propagation of a subglacial flood wave during the initiation of a jökulhlaup. Hydrol. Sci. J., 47(3), 417-434
Kamb B (1987) Glacier surge mechanism based on linked cavity configuration of the basal water conduit system. J. Geophys. Res., 92(B9), 9083-9100 (doi: 10.1029/JB092iB09p09083)

Kessler MA and Anderson RS (2004) Testing a numerical glacial hydrological model using spring speed-up events and outburst floods. Geophys. Res. Lett., 31(18), L18503 (doi: 10.1029/ 2004GL020622)

Magnússon E, Rott H, Björnsson H and Pálsson F (2007) The impact of jökulhlaups on basal sliding observed by SAR interferometry on Vatnajökull, Iceland. J. Glaciol., 53(181), 232-240 (doi: 10.3189/172756507782202810)

Magnússon E and 8 others (2011) Localized uplift of Vatnajökull, Iceland: subglacial water accumulation deduced from InSAR and GPS observations. J. Glaciol., 57(203), 475-484 (doi: 10.3189/002214311796905703)

Mayer C, Lambrecht A, Hagg W, Helm A and Scharrer K (2008) Post-drainage ice dam response at Lake Merzbacher, Inylchek Glacier, Kyrgyzstan. Geogr. Ann. A, 90(1), 87-96 (doi: 10.1111/ j.1468-0459.2008.00336.x)

Ng FSL (1998) Mathematical modelling of subglacial drainage and erosion. (DPhil thesis, University of Oxford)

$\mathrm{Ng} \mathrm{F}$ and Björnsson $\mathrm{H}$ (2003) On the Clague-Mathews relation for jökulhlaups. J. Glaciol., 49(165), 161-172 (doi: 10.3189/ 172756503781830836)

Ng F and Liu S (2009) Temporal dynamics of a jökulhlaup system. J. Glaciol., 55(192), 651-665 (doi: 10.3189/ 002214309789470897)

Ng F, Liu S, Mavlyudov B and Wang Y (2007) Climatic control on the peak discharge of glacier outburst floods. Geophys. Res. Lett., 34(21), L21503 (doi: 10.1029/2007GL031426)

Nye JF (1976) Water flow in glaciers: jökulhlaups, tunnels and veins. J. Glaciol., 17(76), 181-207

Pimentel S and Flowers GE (2011) A numerical study of hydrologically driven glacier dynamics and subglacial flooding. Proc. R. Soc. London, Ser. A, 467(2126), 537-558 (doi: 10.1098/ rspa.2010.0211)

Riesen P, Sugiyama S and Funk M (2010) The influence of the presence and drainage of an ice-marginal lake on the flow of Gornergletscher, Switzerland. J. Glaciol., 56(196), 278-286 (doi: 10.3189/002214310791968575)

Schoof C (2010) Ice-sheet acceleration driven by melt supply variability. Nature, 468(7325), 803-806 (doi: 10.1038/ nature09618)

Spring U and Hutter K (1981) Numerical studies of jökulhlaups. Cold Reg. Sci. Technol., 4(3), 227-244

Sugiyama S, Bauder A, Weiss P and Funk M (2007) Reversal of ice motion during the outburst of a glacier-dammed lake on Gornergletscher, Switzerland. J. Glaciol., 53(181), 172-180 (doi: 10.3189/172756507782202847)

Sugiyama S, Bauder A, Huss $M$, Riesen $P$ and Funk $M$ (2008) Triggering and drainage mechanisms of the 2004 glacier-dammed lake outburst in Gornergletscher, Switzerland. J. Geophys. Res., 113(F4), F04019 (doi: 10.1029/ 2007JF000920)

Sugiyama S, Bauder A, Riesen P and Funk M (2010) Surface ice motion deviating toward the margins during speed-up events at Gornergletscher, Switzerland. J. Geophys. Res., 115(F3), F03010 (doi: 10.1029/2009JF001509)

Sundal AV, Shepherd A, Nienow P, Hanna E, Palmer S and Huybrechts P (2011) Melt-induced speed-up of Greenland ice sheet offset by efficient subglacial drainage. Nature, 469(7331), 521-524 (doi: 10.1038/nature09740)

Walder JS (1986) Hydraulics of subglacial cavities. J. Glaciol., 32(112), 439-445

Zwally HJ, Abdalati W, Herring T, Larson K, Saba J and Steffen K (2002) Surface melt-induced acceleration of Greenland icesheet flow. Science, 297(5579), 218-222 (doi: 10.1126/ science.1072708) 